\title{
Revolutionary Damascene roses: women and media in the Syrian conflict
}

Chapter in edited book Annemarie Profanter, Elena Maestri, Arab women and media in changing landscapes: realities and changes, Cambridge University Press, December 2015

$$
\begin{array}{r}
\text { “... it is only women, women themselves, who can free themselves } \\
\text { from all forms of gender oppression and so become a vital dynamic force } \\
\text { capable of creating another world." }
\end{array}
$$

Nawal Sadawi, "Waging War on the Mind"

Back in 2008, when Syria was still a relatively stable country, marked by that stagnant though fictitious tranquillity that authoritarian regimes are capable of establishing, no one would have imagined how the course of history would have hit this country so harshly only three years later. ${ }^{2}$ No one would have predicted that citizens' tolerance towards the Asad regime would have ended and that many men, women and children would have gone into the streets demanding back their freedom and dignity. No one would have expected that those protests would have grown in size and caught on like wild fire through the whole country. And even less one would have imagined that those protests would have turned into a civil war with international backing and lastly become a self-perpetuating conflict, with no apparent solution feasible. Far from this dreadful scenario, the Syrian novelist Zakaria Tamer published a collection of short stories entitled Breaking Knees in 2008, where with a sarcastic language and visionary power, he explores the intricate interplay of human relations, the repression of the individual in the hands of the institutions or religion and the urgent need for change. ${ }^{3}$

\footnotetext{
${ }^{1}$ Nawal Sadawi, "Waging War on the Mind", (paper presented at the World Social Forum 2004, Mumbai, India, 16-21 January 2004).

${ }^{2}$ See Billie Jeanne Brownlee, Maziyar Ghiabi, "Passive, Silent and Revolutionary: the Arab Spring Revisited", (unpublished paper presented at SeSamo Conference, Ca' Foscari University of Venice, January 15-17, 2015).

${ }^{3}$ Original title "Taksir Rukab" See English version, Zakaria Tamer, Breaking Knees, trans. Ibrahim Muhawi, (Reading: Garnet Publishing, 2008).
} 
In one of these short stories we may read the Syrian war of these days in metaphorical terms. ${ }^{4}$ This is the story of a town in Syria, not explicitly named, with two neighbourhoods: a central (aljawaniya) and a peripheral (al-baraniya) one. ${ }^{5}$ The two neighbourhoods lived peacefully side by side, sharing common spaces like mosques, markets and cafés. Suddenly a quarrel between the two neighbourhoods burst into flame and endured with unprecedented violence every lasting day. The fuse that lit the revolt, a frivolous comment on women's costumes is forgotten in the fog of the revolt while the fight enlarges and the reciprocal anger grows. The increase in violence and the unwillingness of the two sides to find a compromise, obliges the international community to intervene and to send a man representing an internationally known organization (the United Nations, though not explicitly mentioned in the text) to resolve the fight and bring peace in the region. This man succeeds in granting interviews with international news channels, organizing events and building his house on the border between the two neighbourhoods: important symbolic results, but nothing more is achieved. The fight comes to an end when the women of the two neighbourhoods secretly meet and with a wise strategy decide to appease their men by spreading white lies, which can mend the wounds and re-establish a citizenry glue based on those values that had made that town live in harmony for such a long time. The story, though intentionally fictional and humorous, is incredibly enlightening for the similarities that it presents with the ongoing conflict in Syria, though in metaphorical terms, like the ineffective intervention of the United Nations and international community, incapable (or unwilling) of understanding the reality on ground and above all, the role of women, victims in the first person of the fight and yet precious agents of peace. ${ }^{6}$

\footnotetext{
${ }^{4}$ All the short stories are untitled, as if each story though independent from the rest, exists within the mosaic of the book.

${ }^{5}$ This short story, as the whole book, abounds in Syrian dialect terminology, adding realism to a strongly fictional plot.

${ }^{6}$ The plot may recall the story of the film Wa Halla' la wayn? (Where do we go now?) by Nadine Labaki's where women's role is key to the conflict resolution of a small though representative Lebanese village. Where Do We Go Now?, directed by Nadine Labaki, (France: Les Films des Tournelles, 2011).
} 
Great historical moments have gone down in history without mentioning women's contribution or without even mentioning their presence. When it comes to great events like wars or revolutions, women appear in the history pages simply as victims of violence, undergoing the action of those in power rather than active moulders of their own destiny and of that of their countries. And yet women are often chosen to embody symbols of the nation, as in the case of France's La Marianne or of the United States' Statue of Liberty, though in the end men are the ones representing it. ${ }^{7}$ History has had an indisputable preference for male characters, offering women only the role of walk-on actors. Many scholars have tried to provide for this lapse of historical memory by reanalysing past events and looking for forgotten female figures who appear in the backstage as fading figures. ${ }^{8}$ Today, though the fight for women's rights and opportunities has still a long way to go, even in more developed and democratic countries, women can rely on the Internet and social media to write their own history, bypassing the gender censorship that has been in vogue this far. The new media become strong empowering tools for women, creating spaces for discussion and exchange of ideas, information venues and mostly instruments capable of changing people's mentality and cultural values over the years.

The Arab upheavals constituted a springboard for Arab women to insert the recognition of women's rights opportunities into the agenda of their countries' revolution, as part of the struggle for equal citizenship and political participation. ${ }^{9}$ In this sense, the "Arab Spring” has not been a political revolution only, but a gender-revolution as well, eradicating fossilized autocrats, as well as gender

\footnotetext{
${ }^{7}$ Karima Omar, "National Symbolism in Construction of Gender: Transformed Symbols in Post-Conflict States", Seton Hall's Journal of Diplomacy and International Relations 5, no.1 (2004), 49-67.

${ }^{8}$ Some relevant scholarship on the topic can be found under subaltern historiography. See Gayatri C. Spivak, "Can Subaltern Speak?" in Cary Nelson, Lawrence Grossberg ed., Marxism and the Interpretation of Culture, (Chicago: University of Illinois Press, 1988), 271-313; Tina Davidson, Ruth R. Pierson, "Voices From the Margins Subaltern Women Speak...and Rewrite History", Journal of Women's History 13, no. 2 (2001), 169-179, accessed August 24, 2014, doi: 10.1353/jowh.2001.0045; Nupur Chaudhri ed., Contesting Archives: Finding Women in the Sources, (Chicago: University of Illinois, 2010).

${ }^{9}$ Due to a lack of precise terminology to refer to the MENA region, this paper makes use of expressions "Arab world", "Middle East" and the "region" interchangeably, aware of the mixture of racial and ethnic groups, social classes, religious affiliations, nationalities, rural and urban settings and linguistic communities. Any discussion on gender takes into consideration this variety, though tries to delineate some general patterns, without assuming that they apply everywhere.
} 
discrimination and gender stereotyping entrenched in the culture. The reliance on the new media allowed women to overcome traditional norms of participation and gain wide visibility, redefine the boundaries of private and public spheres, connect national and international audiences, initiate a dialogue with policymakers and exhort pressure. By doing so, they are opening a new chapter in the history of this region and in the history of Arab women's activism more specifically. ${ }^{10}$

In this light, this chapter attempts to shade light on angles not widely covered by the mainstream media, that is to say women's vital role in the Syrian uprising, by tracking their footprints in the transformation of the political landscape that is taking place in their country. ${ }^{11}$ It displays the actions of women as human agents and inquiries into how social structures of identity and authority shape the possibilities for female actions in times of instability. The analysis draws specific attention to the enabling effects of the new media and information technology, which have empowered large segments of the country's population, among which women. These tools acted as the "change agent" in the fight for women's empowerment, allowing them to articulate their identities online, take on roles of civic and political responsibility in such historical phase of their country, which one would hope will not be denied at the end of such dramatic change of their history. ${ }^{12}$ Certainly, the new media guarantee a more gender-equal writing of our history, which will not relegate women to the sidelines, as has happened in the Arab revolutions in the $20^{\text {th }}$ century. ${ }^{13}$

\footnotetext{
10 Sahar Khamis, "Islamic feminism in new Arab media: platforms for self-expression and sites for multiple resistances", Journal of Arab and Muslim Media Research 3, no. 3 (2010), 237-255, accessed August 20, 2014, doi:http://dx.doi.org/10.1386/jammr.3.3.237_1

${ }^{11}$ This paper draws on extensive desk research, extensive field observation, both on-line and on the ground, accompanied by in-depth interviews with female civil society activists working in Syria and abroad. Interviews were conducted face-to-face in Lebanon and Turkey and when not possible, via Skype. Given the extremely insecure situation in Syria, the reference to people, organizations and places that might endanger the people involved in this work, will not be disclosed.

12 “The Role of Social Media in Arab Women's Empowerment", Arab Social Media Report 1, no. 3, November 2011, http://www.arabsocialmediareport.com/UserManagement/PDF/ASMR\%20Report\%203.pdf, accessed June 29, 2014.

${ }^{13}$ Just to mention the incredible role that women had during Algeria's war for independence (1954-1962). Women became active participants on the side of the National Liberation Front (FLN), as combatants, spies, nurses, cooks. A partial but still initial historical recognition of women's role in Algeria's War for Independence appears in the masterpiece The Battle of Algiers, directed by Gillo Potecorvo, (Rome: Rizzoli, 1996).See, Natalya Vince, "Saintly
} 
If the uprising in the MENA was a poignant moment for women in terms of participation, visibility and achievements, Arab feminism was not a 2011 phenomenon, but a movement with a long history, dating back more than a century. Likewise, women's activism in Syria did not emerge in the midst of the uprising merely as the effect of a survival-mode or of the necessity to cope with a war-like and humanitarian emergency. Women's activism in Syria, as expressed since the very beginning of the uprising, was the result of a decade long phenomenon of civil society initiatives. Since the beginning of the presidency of Bashar al-Asad in 2000, many feminist associations and committees started growing, pushing for reforms and more recognition in public spaces. ${ }^{14}$ In fact, in the decade predating the uprising, Syrian women had built strong networks across the country, working to challenge gender stereotypes, strengthen their status and amend discriminatory laws.

It is worth presenting some of the initiatives that were carried out in the pre-revolutionary period, in order to understand women's participation and struggle in the uprising in a more coherent framework. The growth of feminist organizations during the presidency of Bashar al-Asad happened through both formal and informal channels, that is to say with or without the regime's approval. The regime turned a blind eye on associations that focused on social matters without dealing with political issues explicitly, as they were not seen to be jeopardizing the regime's stability. ${ }^{15}$ Instead, all those organizations that fought for the protection of women's rights and status in public spheres were thwarted by the regime and relegated to mere on-line websites, often shut down. ${ }^{16}$ Al-Thawra (www.thara-sy.com) and the Syrian Women Observatory (www.nesasy.org) were the first websites engaged in the improvement of women's and children's

grandmothers: youth reception and reinterpretation of the national past in contemporary Algeria", The Journal of North African Studies 18, no. 1 (2013): 32-50. Accessed July 11, 2014, doi: 10.1080/13629387.2012.728049.

${ }^{14}$ Yahya Al-Aous, "Feminist Websites and Civil Society Experience" in Syrian Voices from Pre-Revolution Syria: Civil Society Against all Odds, (The Hague: HIVOS, 2013), 23-28.

${ }^{15}$ To mention the General Union of Syrian Women (which represents Syria in the relevant UN programmes and agencies), the Syrian Women's League and the Association for Women's role Development (AWRD). See, Hanadi Trafieh, "Women's Rights, Gender and ICTs in Syria", GISWatch, 2013, http://www.giswatch.org/en/countryreport/womens-rights-gender/syria, accessed July 1, 2014.

${ }_{16}$ Al-Aous,"Feminist Websites", 23. 
rights. ${ }^{17}$ These websites became a reference point for many women in Syria, publishing information about associations active in diverse fields such as youth, people with special needs, prisoners, environment, health and so forth; establishing a network of connections with associations engaged in women and children's rights; raising awareness on sensitive topics and most importantly providing shelter and legal advice to women who suffered from domestic violence or threats to their life. $^{18}$

The issue of raising awareness about the existing laws has been one of the main concerns of feminist activism. By providing access to legal libraries and setting up informal groups of jurists and experts offering legal advice, many women were now capable of understanding their actual rights and the legal tools available to them and act accordingly. ${ }^{19}$ This type of activism did not just face the regime's ostracism, but that of the conservative religious elites as well. ${ }^{20}$ The conservative religious elite, tightly tied to the new regime, thwarted the feminist websites with the justification that they were seeking to destroy morality and were propagating Western values (i.e. civil marriage). ${ }^{21}$ These websites helped to counter the atomization of society by carrying out successful civil campaigns, such as the Campaign Against Honour Crimes, the Personal Status Law and the Children in Danger campaign. ${ }^{22}$ Interestingly these campaigns took place predominately online, bringing women and men together to discuss erroneous practices prevailing in Syrian society, raising awareness by exposing numerous crimes and signing online petitions, which were later sent to the president and relevant ministries. This type of activism gained successful results with the Campaign against Honour Crime (2008) which brought an amendment to Article 548 of the Penal Code, increasing punishment from one year to two years, a small but still relevant step forward. ${ }^{23}$

\footnotetext{
${ }^{17}$ Roschanack Shaery-Eisenlohr, Francesco Cavatorta, "The Internet and Civil Activism in Syria" in Paul Aarts and Francesco Cavatorta ed., Civil Society in Syria and Iran, (London: Lynne Rienner, 2013), 126-132.

18 Ibid., 25.

19 Ibid., 28.

${ }^{20}$ Ibid., 24.

${ }^{21}$ Ibid., 25.

${ }^{22}$ Shaery-Eisenlohr, "The Internet and Civil Activism", 128.

${ }^{23}$ Jane Gabriel, "Syria Women's rights: The fight does not stop here", Open Democracy, December 8, 2008, http://www.opendemocracy.net/audio/syrian-womens-rights-the-fight-does-not-stop-here, accessed April $03,2014$.
} 
Equally important was the Personal Status Law campaign, which succeeded in getting sent back for further examination the draft of a new Personal law, formulated by a conservative Islamic committee which would have represented a setback for civil rights, especially for women. ${ }^{24}$ In addition to these large scale campaigns, there have been a number of smaller initiatives taking place since 2006, like a campaign for the protection of young women who had been victims of rape and one to give mothers the right to give their nationality to their children. ${ }^{25}$ The high reliance on the Internet and the social web was the key to the success of these campaigns as well as to the existence of these types of organizations, as an outlet of visibility and communication with the public. An example is represented by Musawa (equality), an independent civil society organization funded in 2009 by a group of Syrian women to fight gender-discrimination and enable effective participation of women in the political, social, economic and cultural spheres of Syrian society. ${ }^{26}$ The reliability and professional outlook of the website, periodically updated with local, regional and international news, has made it one of the most comprehensive resources on the subject for women in Syria and the whole Arab region. ${ }^{27}$ The availability of the new information and communication technology has been fundamental for the existence and success of these activities, offering new ways of learning, organizing and coordinating actions.

\section{Female activism in the midst of the uprising/ civil war}

The Syrian uprising is said to have started on the $15^{\text {th }}$ of March of 2011, in concomitance with the protests taking place in Dera'a demanding the release of fifteen children who had painted anti-

\footnotetext{
24 Amjad Baiazy, "Syria's Cyber Wars", Media Policy, January 2013, https://www.yumpu.com/en/document/view/10861545/by-amjad-baiazy-media-policy, accessed September 12, 2014, 13 Also see, Wael Sawah, "The Dialect Relationship between the Political and the Civil in the Syrian Society Movement”, Arab Reform Initiative 34 (2009), http://www.arab-reform.net/dialectic-relationship-between-political-andcivil-syrian-civil-society-movement, accessed April 7, 2014.

${ }^{25}$ Al-Aous, "Feminist Websites", 27-28.

${ }^{26}$ Trafieh, "Women's Rights".

27 Ibid.
} 
government graffiti on the walls of their school, inspired by the revolution in Tunisia and Egypt. ${ }^{28}$ Accounts say that the parents who were asking for the release of their children had been told: "make new ones! And if you don't know how to do it, send over your women and we'll help you". ${ }^{29}$ This time, this arrogance and chauvinist non-respect towards citizens, women and mothers had reached the bottom. If the initial protests were tempered by mild demands of reforms, more democratic institutions and the uprooting of corruption, with the increase in the regime's violence, the protestors demanded the removal of the president and the Ba'ath party from power. The first person ever to dare to publicly ask president Bashar al-Asad to step down was in fact a woman, Muntha Al-Atrash. Muntha is a human rights lawyer, coming from the minority Druze community and the daughter of Sultan Atrash, the leader of the so-called "Greater Syrian revolution" of 1925 against the French mandate.$^{30}$ On a phone interview with Al-Sharq Al-Awsat newspaper on April 12, 2011 she openly addressed the president by saying “... now, after all this bloodshed, I can only say that it would be better for him and for Syria if he steps down from power. I would tell him, honour the blood of your people and step down from power with your head held high. You are a dentist, you can return and reopen your clinic and work as a dentist". ${ }^{31}$ This brave gesture was incredibly important for the development of the Syrian uprising, strengthening the cause of the protestors and encouraging people to depose their fear and speak out. However, her words were even more inspiring to other women, boosting them to take part in the uprising and build global public support for their causes, using social media and Internet-based platforms to do so. In each country, there were women who stirred the heart of their fellow citizens to mobilize and put an end to the customary limits of female participation in formal politics; in short a revolution within the revolution. For this to happen, it was crucial for women to actively contribute to the political struggle from the early stages of the uprising, in order not to allow men to hijack the revolution and

\footnotetext{
${ }^{28}$ Carsten Wieland, Syria. A Decade of Lost Chance, (Seattle: Cune Press, 2012), 20.

${ }^{29}$ Ibid.

30 Razan Ghazzawi, Seeing the women in revolutionary Syria, OpenDemocracy, April 8, 2014, http://www.opendemocracy.net/arab-awakening/razan-ghazzawi/seeing-women-in-revolutionary-syria, June 9, 2014.

${ }^{31}$ Ibid.
} 
its narrative. The new media played a fundamental role in showing that women were an essential part of the process for change, as it has been the case of Muntha al-Atrash with Al-Sharq al-Awsat; similar to Asma Mahfouz's video blog posted on Facebook on the $18^{\text {th }}$ January challenging Egyptian men to join her in protesting on 25 January $2011,{ }^{32}$ or to the recording of Ayat alQurmezi's anti-regime poems in Bahrain's Pearl Square and their subsequent circulation via social media, ${ }^{33}$ and the images of Tawwakol Karman, the first Arab woman to win a Nobel prize, ${ }^{34}$ leading a protest of women journalists in Yemeni's capital. ${ }^{35}$

Other women followed Muntha's example, carrying out courageous actions thus boosting women's self-confidence to join the struggle. A remarkable female activist is Rima Dali, an Alawite, who has been campaigning for nonviolent resistance since the early start of the upheaval, organizing manifestations, often with strong symbolic connections. ${ }^{36}$ In April 2012, she stood in the middle of the main road outside the Parliament in Damascus, causing a gridlock by holding a big banner that said "Stop the killing! We want to build a country for all Syrians". ${ }^{37}$ With this act she was identifying the Parliament as the one that should be representing its people and inserting the issue of women's rights and equality in its agenda. She became known as the "girl in the red dress", for the short red dress that she was wearing that day, a clear message of her femininity and self-confidence. In November of 2012, Rima Dali was arrested for leading the "Brides of Peace" demonstration in downtown of Damascus's main souk, where women dressed in white wedding dresses marched

32 "Meet Asma Mahfouz and the Vlog that Helped Spark the Revolution", YouTube, https://www.youtube.com/watch?v=SgjIgMdsEuk, accessed June 29, 2014.

33 "Bahrain student jailed for year over protest poem", The Guardian, June 12, 2011, http://www.theguardian.com/world/2011/jun/12/bahrain-student-jailed-protest-poems, accessed June 29, 2014.

34 Abubakr Al-Shamahi, "Tawakkol Karman: Nobel Prize Laureate", Al-Jazeera English, October 9, 2011, http://www.aljazeera.com/indepth/opinion/2011/10/201110813924645224.html, accessed June 29, 2014.

${ }^{35}$ Courtney Radsch, Sahar Khamis, "In Their Own Voice: Technologically Mediated Transformation among Young Arab Women”, Feminist Media Studies 3: (2013), 881-890, accessed August 30, 2014, doi: 10.1080/14680777.2013.838378.

36 "Syria: Activist Rima Dali Arrested in Damascus for Calling for End to Killing", Global Voices, April 9, 2012, http://globalvoicesonline.org/2012/04/09/syria-activist-rima-dali-arrested-in-damascus-for-calling-for-end-to-killing/, accessed July 10, 2014.

${ }^{37}$ Ibid. 
demanding the end of violence. ${ }^{38}$ The fact of underlining her femininity through her outfit and demands denotes the will to preserve her female features and most importantly not be identified with masculine characteristics, as very often has been done when it comes to describing women's acts of bravery. This type of activism might at first be perceived as showy and not expressively pursuing concrete achievements; however it bolstered women's participation in the everyday resistance.

Other female public figures stood up to the brutality of the regime, like Fadwa Suleiman, a famous Syrian actress of Alawite descend, who participated in the frontlines of peaceful demonstrations across the country and spread video messages online, calling people to hold back their fears and keep protesting in the streets. ${ }^{39}$ Another Alawite figure, Samar Yazbek, renowned writer, joined the protestors and voluntarily stood in the frontline of the demonstrations. ${ }^{40}$ The regime, first, put the author in prison and then obliged her to leave the country. She has recently released a novel, $A$ Woman in the Crossfire-Diary of the Syrian Revolution, on the challenges of being a woman during a revolution. ${ }^{41}$ Clearly, women like the ones described this far managed to reach an international stage and somehow get away from the tragedy afflicting their country, while the rest have been fighting the real conflict on the ground, paying a higher price without the glory. However, these figures have still represented a positive role, fighting for a common cause and inspiring emulation to other women, debunking the traditional image of Arab women as hopeless and vulnerable actors.

Other Syrian women have been participating in the uprising in less visible though very meaningful and substantial ways. Women like Razan Zeitouneh, who was kidnapped by an unknown armed group in the Douma suburbs of Damascus, had been working behind the scene, and literally

\footnotetext{
${ }^{38}$ She was released with her three fellows in early January 2013. "Syrian 'Peace Brides' Forcibly Disappeared," Amnesty International, December 7, 2012, http://www.amnesty.org/en/library/asset/MDE24/090/2012/en/d2884e0559a2-4337-90ef-47d94748a376/mde240902012en.html.

${ }^{39}$ Khaled Yacoub Oweis, "Syrian Actress treads New Stage in Syrian Protests", Reuters, January 5, 2013, http://uk.reuters.com/article/2012/01/05/us-syria-actress-idUSTRE8040WQ20120105, accessed July 10, 2014.

${ }^{40}$ Aida Edemariam, "Syrian writer Samer Yazbek: a woman like me makes life difficult", The Guardian, October 13, 2012, http://www.theguardian.com/books/2012/oct/13/interview-samar-yazbek-syria-revolution, accessed July 11, 2014.

${ }^{41}$ Samar Yazbek, A woman in the Crossfire, trans. Max Weiss, (London: Haus Publishing, 2012).
} 
underground, to document violations coming both from the regime and the rebel armed group operating in the country. ${ }^{42}$ Razan is the co-founder of the widely respected Local Coordination Committees (LCC) and of the Violation Documentation Centre (VDC), the only platform inside Syria that takes note of all the Syrian martyrs, detainees and kidnapped civilians and documents human rights abuses committed by all sides. ${ }^{43}$ Her activism had started thirteen years before the spark of the uprising, when, as a lawyer, she provided legal support for numerous political prisoners in court, a place that Syrians did not trust and often would not dare attend. ${ }^{44}$ For her work and commitment she received the Sakharov Prize and the Anna Politkovskaya Prize in 2011, and in 2013 the International Women of Courage award. ${ }^{45}$

Another woman, Razan Ghazzawi has been a tireless defender of human rights not only in Syria but throughout the Arab World. ${ }^{46}$ Already active before the start of the uprising, since 2011 she has become a symbol of resistance to repression for women, bloggers, journalists and the like. Razan has transformed her blog and social media into powerful weapons to raise awareness, promote dissent and expose the crimes committed by the regime. Convinced of the role of journalists and bloggers as people capable of bringing positive changes to society, she advocated for their rights by collaborating at the Syrian Centre for Media and Freedom of Expression, a partner organization of Reporters Without Borders operating underground in Syria since 2004. ${ }^{47}$ Clearly, her activism has been fiercely hindered by the regime, shutting her blog and detaining her in several occasions. ${ }^{48}$

\footnotetext{
42 "Who's who: Razan Zaitouneh", The Syrian Observer, August 19, 2013,http://www.syrianobserver.com/Opposition/Opp_Who/Whos+who+Razan+Zaitouneh, accessed July 02, 2014.

${ }^{43}$ Ghazzawi, "Seeing the women".

44 "Syrian woman human rights attorney still missing from Damascus, Women News Network, December 4, 2013 , http://womennewsnetwork.net/2014/01/18/syrian-woman-rights-attorney/, accessed July 11, 2014.

45 Ibid.

46 Jared Malsin, "Portrait of an Artist: Razan Ghazzawi, the Syrian Blogger turned Exile", Time, April 2, 2013 , http://world.time.com/2013/04/02/portrait-of-an-activist-meet-razan-ghazzawi-the-syrian-blogger-turned-exile/, accessed July 11, 2014.

${ }^{47}$ Syrian Centre for media and freedom of expression: http://scm.bz/?lang=en.

48 Jillian C. York, "Why Syria's arrested blogger, Razan Ghazzawi, is one of my heroes", The Guardian, December 5, 2011, http://www.theguardian.com/commentisfree/2011/dec/05/syria-arrested-blogger-razan-ghazzawi, accessed July 11,2014
} 
The use of the new media has also been essential for the Syrian Women for the Syrian Intifada (SANAD), a network of women initially aimed at supporting families of detainees and martyrs, which later broadened its activities to support grassroots' activists who had lost their jobs or of those who had gone into hiding for their political stances. ${ }^{49}$ Through the new media the group advertises its activities, reaches people in need, enlarges its network and collects funds to support activists working in the media and humanitarian relief sector. Unlike other groups of hard-working female activists, SANAD has been particularly successful in forming a programme and delivering its goals, given the experience and maturity of its members. ${ }^{50}$ SANAD is just one among the numerous female organizations keeping up the values of the revolution, organizing initiatives and assisting those in need. Other groups of women have been active in the demonstration and information campaign, protesting and widening the rows of those who had not taken a stand in the revolution, for fear or preference of non-commitment. For example, the Derayya's Free Women, active since the spring of 2011, is a civil grassroots movement of women engaged in civil resistance. ${ }^{51}$ The women of Derayya have been carrying out sit-ins and demonstrations to demand the release of prisoners of conscience and the end of violence from both the regime and the Islamists; organizing meetings to plan strategies; offering workshops to teach women to promote changes in their country, but also providing humanitarian and psychological support. The new media have been essential for the survival of this group and of many others, given the restrictions imposed by a civil war engulfing the country, which makes mobility and visibility very difficult. To overcome these limits, the Salamiyah Women Coordination Committee, has come up with innovative but safer means of protesting: domestic sit-ins and protest happening inside homes, where women holding banners with political slogans are filmed and then distributed on social

\footnotetext{
49 SANAD (نساء سوريات لدعم الانتفاضة السورية), Facebook page, accessed July 12, 2014, http://ivrytwr.com/2012/04/11/how-to-cite-facebook.

${ }^{50}$ Ghazzawi, "Seeing the women".

51 "Syria. The Free Women of Derayya", Global Voices, December 20, 2013, http://globalvoicesonline.org/2013/12/20/syria-the-free-women-of-darayya/, accessed July 11, 2014.
} 
media. ${ }^{52}$ This way the new media become a survival device to the silence and fear that the horror of the war instils in people, a relief valve to speak out, raise awareness and lift the spirits of those living the same experience.

The array of Syrian women activists presented this far is only a fragment of the actual phenomenon. In fact, the space constraints accorded to this paper and the availability of data on a country at war have limited the selection of cases to treat. More words are needed to celebrate all those women who in Syria are fighting a battle on two-fronts: the one of the conflict and the more deep-rooted confrontation of being a woman in a context where gender equality has a long way ahead. Syrian women have proved not to fit the category of the "weaker gender", having not pulled back from any responsibility, being in the forefront of protest movements, leading demonstrations, documenting the revolt, working in the media, providing humanitarian assistance, smuggling food, medicines and weapons and not least by helping to construct makeshift bombs in their homes and fighting in the battlefields. ${ }^{53}$ Some have joined men on the ground or as snipers, some have created their own paramilitary fighting troop, like the Katiba or battalion, a group of mostly Kurdish women fighting alongside the Free Syrian Army. ${ }^{54}$ Unfortunately most of this female activism rarely reaches the attention of the media, but nonetheless representing a capital change in the cultural and social fabric of Syria.

\section{Concluding Remarks}

This paper represents a small contribution to this book's mosaic on Arab feminism and new media in times of revolts, conflicts and instability. Syrian women have received less media coverage than their counterparts in the rest of region affected by the upheavals. And yet their activism has proved

\footnotetext{
52 "The women of Salamiayh turn Houses into Protest Squares", Syria Untold, May 10, 2014, http://www.syriauntold.com/en/story/2014/05/10/9375, accessed July 09, 2014.

${ }^{53}$ Friday Files, "Women Organizing to Survive: Syria's Civil Society and Beyond”, Thomson Reuters Foundation, July 5, 2013, http://www.trust.org/item/20130705155822-kqita/, accessed August 30, 2014.

${ }^{54}$ A pro-regime female paramilitary squadron has been fighting for the regime, under the name of "The Lioness of Syria". See, "Assad's Lionesses: the female last line in the battle for Syria", The Independent, January 22, 2013, http://www.independent.co.uk/news/world/middle-east/assads-lionesses-the-female-last-line-in-the-battle-for-syria8462221.html, accessed July 12, 2014.
} 
exceptional given the indisputable tremendous reality that a three-year-old conflict and humanitarian crisis have produced. In such a context, it is difficult to draw a final reflection given that there is still no conclusive outcome to the revolution. What is certain is that the uprising in 2011 became an opportunity for Syrian women to insert their personal struggle into the agenda of the revolution, women's rights as part of the call for democracy. The reliance on the new media tools has been decisive to lay the ground for the uprising, raise awareness for their personal struggles and for the Syrian crisis. For many women political participation and the use of the new media was a new experience, others instead had been involved in women's rights issues and informatics long before the uprising. Many women have been active on-line, others off-line, each one nurturing from the work and experience of the other. The coalition of these two worlds, the old and the new generation, the maturity of one and the idealism and rigor of the other, combined with the use of traditional to new digital forms of activism have made Syrian women a strong actor in the transformation that is taking place in the country. However, the fight for women's rights in Syria still has a long way to go, if one considers that they remain unrepresented in the Syrian National Council, the organism that should govern the country in the transition period (holding only twentyfour of the 444 seats) and in the Geneva Peace Talks in February 2014, where no Syrian woman was invited. ${ }^{55}$ Moreover with the rise of the Islamist movements and ideology, operating in the country and transnationally, a dark light looms on their already curvy path. ${ }^{56}$ Despite all the difficulties that the destiny has in store, Syrian women have demonstrated to be more willing to fight openly for their rights and to be more capable of confronting stereotypes and barriers of participation. Whatever destiny is set aside for this country, women have learned through the media

\footnotetext{
55 "Video: No Syrian Women were invited to the peace talks-watch them speak up", Your Middle East, February 13, 2014, http://www.yourmiddleeast.com/videos/video-no-syrian-women-were-invited-to-the-peace-talks-watch-themspeak-up 21586, accessed July 9, 2014.

56 Matthew Weaver, "Isis declares caliphate in Iraq and Syria", The Guardian, June 30, 2014, http://www.theguardian.com/world/middle-east-live/2014/jun/30/isis-declares-caliphate-in-iraq-and-syria-live-updates, accessed July 12, 2014.
} 
to become visible, to express themselves freely and to penetrate every public sphere in a way that seems irreversible for this new generation. ${ }^{57}$

${ }^{57}$ Courtney Radsch, "Arabic Twitter stars come face to face in Cairo", Women's E-News, January 26, 2012 , http://womensenews.org/story/media-stories/120125/arabic-twitter-stars-come-face-face-in-cairo\#.VAHfOmPgV7k, accessed August 30, 2014. 


\section{Bibliography}

"Assad's Lionesses: the female last line in the battle for Syria." The Independent. January 22, 2013. Accessed July 12 , 2014. http://www.independent.co.uk/news/world/middle-east/assads-lionesses-the-female-last-line-in-the-battle-forsyria-8462221.html.

"Bahrain student jailed for year over protest poem." The Guardian. June 12, 2011. Accessed June $29,2014$. http://www.theguardian.com/world/2011/jun/12/bahrain-student-jailed-protest-poems.

"Syria. The Free Women of Derayya." Global Voices. December 20, 2013. Accessed July $11,2014$. http://globalvoicesonline.org/2013/12/20/syria-the-free-women-of-darayya/.

"Syria: Activist Rima Dali Arrested in Damascus for Calling for End to Killing." Global Voices. April 9, 2012. Accessed July 10, 2014. http://globalvoicesonline.org/2012/04/09/syria-activist-rima-dali-arrested-in-damascus-forcalling-for-end-to-killing/.

“Syrian 'Peace Brides’ Forcibly Disappeared." Amnesty International. December 7, 2012. Accessed August $20,2014$. http://www.amnesty.org/en/library/asset/MDE24/090/2012/en/d2884e05-59a2-4337-90ef47d94748a376/mde240902012en.html.

"Syrian woman human rights attorney still missing from Damascus." Women News Network, December 4, 2013. Accessed July 11, 2014. http://womennewsnetwork.net/2014/01/18/syrian-woman-rights-attorney/.

“The Role of Social Media in Arab Women's Empowerment." Arab Social Media Report 1, no. 3 (November 2011), Accessed June 29, 2014. http://www.arabsocialmediareport.com/UserManagement/PDF/ASMR\%20Report\%203.pdf.

"The women of Salamiayh turn Houses into Protest Squares." Syria Untold. May 10, 2014. Accessed July 09, 2014.http://www.syriauntold.com/en/story/2014/05/10/9375.

"Video: No Syrian Women were invited to the peace talks-watch them speak up." Your Middle East. February 13, 2014. Accessed July 9, 2014. http://www.yourmiddleeast.com/videos/video-no-syrian-women-were-invited-to-thepeace-talks-watch-them-speak-up_21586.

“Who's who: Razan Zaitouneh”. The Syrian Observer. August 19, 2013. Accessed July $02,2014$. http://www.syrianobserver.com/Opposition/Opp_Who/Whos+who+Razan+Zaitouneh.

"Women Organizing to Survive: Syria’s Civil Society and Beyond." Thomson Reuters Foundation. July 5, 2013. Accessed August 30, 2014. http://www.trust.org/item/20130705155822-kqita/.

Al-Aous, Yahya. "Feminist Websites and Civil Society Experience." in Syrian Voices from Pre-Revolution Syria: Civil Society Against all Odds, The Hague: HIVOS, 2013.

Al-Shamahi, Abubakr, “Tawakkol Karman: Nobel Prize Laureate”, Al-Jazeera English, October 9, 2011. Accessed June 29, 2014. http://www.aljazeera.com/indepth/opinion/2011/10/201110813924645224.html,

Baiazy, Amjad, “Syria’s Cyber Wars.” Media Policy. January 2013. Accessed August $23,2014$. https://www.academia.edu/3555530/Syria_Cyber_Wars.

Brownlee, Billie Jeanne and Ghiabi, Maziyar "Passive, Silent and Revolutionary: the Arab Spring Revisited". Paper presented at SeSamo Conference 2015, Ca’ Foscari University of Venice, Italy, January 15-17, 2015.

Chaudhri, Nupur ed. Contesting Archives: Finding Women in the Sources. Chicago: University of Illinois, 2010.

Davidson, Tina, and R. Pierson, Ruth. "Voices From the Margins Subaltern Women Speak...and Rewrite History." Journal of Women's History 13, no.2 (2001), 169-179. Accessed August 24, 2014, doi: 10.1353/jowh.2001.0045.

Edemariam, Aida. "Syrian writer Samer Yazbek: a woman like me makes life difficult." The Guardian. October 13, 2012. Accessed July 11, 2014.http://www.theguardian.com/books/2012/oct/13/interview-samar-yazbek-syriarevolution.

El- Baghdadi, Iyad. "Meet Asma Mahfouz and the Vlog that Helped Spark the Revolution." YouTube. Uploaded February 1, 2011. Accessed June 29, 2014. https://www.youtube.com/watch?v=SgjIgMdsEuk.

Gabriel, Jane. "Syria Women's rights: The fight does not stop here." OpenDemocracy, December 8, 2008. Accessed April 03, 2014. http://www.opendemocracy.net/audio/syrian-womens-rights-the-fight-does-not-stop-here.

Ghazzawi, Razan. Seeing the women in revolutionary Syria. OpenDemocracy. April 8, 2014. Accessed June 9, 2014. http://www.opendemocracy.net/arab-awakening/razan-ghazzawi/seeing-women-in-revolutionary-syria.

Khamis, Sahar. "Islamic feminism in new Arab media: platforms for self-expression and sites for multiple resistances." Journal of Arab and Muslim Media Research 3. no. 3 (2010), 237-255. Accessed August 20, 2014, Doi: http://dx.doi.org/10.1386/jammr.3.3.237 1

Labaki, Nadine (film). Where Do We Go Now? France: Les Films des Tournelles, 2011. 
Malsin, Jared. "Portrait Of an Artist: Razan Ghazzawi, the Syrian Blogger turned Exile". Time. April 2, 2013. Accessed July 11, 2014. http://world.time.com/2013/04/02/portrait-of-an-activist-meet-razan-ghazzawi-the-syrian-blogger-turnedexile/.

Omar, Karima. "National Symbolism in Construction of Gender: Transformed Symbols in Post-Conflict States." Seton Hall's Journal of Diplomacy and International Relations 5, no. 1 (2004), 49-67.

Pontecorvo, Gillo (film). The Battle of Algiers. Rome: Rizzoli, 1996.

Radsch, Courtney, and Khamis, Sahar. "In Their Own Voice: Technologically Mediated Transformation among Young Arab Women." Feminist Media Studies 3: (2013), 881-890. Accessed August 30, $2014 . \quad$ doi: 10.1080/14680777.2013.838378.

Radsch, Courtney. “Arabic Twitter stars come face to face in Cairo.” Women's E-News. January 26, 2012. Accessed August 30, 2014. http://womensenews.org/story/media-stories/120125/arabic-twitter-stars-come-face-face-incairo\#.VAHfOmPgV7k.

Sadawi, Nawal. "Waging War on the Mind." Paper presented at the World Social Forum 2004, Mumbai, India, 16-21 January 2004.

Sawah, Wael. "The Dialect Relationship between the Political and the Civil in the Syrian Society Movement." Arab Reform Initiative 34 (2009). Accessed April 7, 2014. http://www.arab-reform.net/dialectic-relationship-betweenpolitical-and-civil-syrian-civil-society-movement.

DSANA) Syrian Women for the Syrian Intifada - نساء سوريات لدعم الانتفاضة السوري). Facebook page. Accessed July 12 , 2014. http://ivrytwr.com/2012/04/11/how-to-cite-facebook.

Shaery-Eisenlohr, Roschanack, and Cavatorta, Francesco, "The Internet and Civil Activism in Syria." in Civil Society in Syria and Iran. Edited by Paul Aarts and Francesco Cavatorta, 126-132. London: Lynne Rienner, 2013.

Spivak, Gayatri C. "Can Subaltern Speak?." in Marxism and the Interpretation of Culture, edited by Cary Nelson, Lawrence Grossberg, 271-313. Chicago: University of Illinois Press, 1988.

Tamer, Zakaria. Breaking Knees. Translated by Ibrahim Muhawi. Reading: Garnet Publishing, 2008.

Trafieh, Hanadi, “Women's Rights, Gender and ICTs in Syria.” GISWatch, (2013). Accessed July 1, 2014, http://www.giswatch.org/en/country-report/womens-rights-gender/syria.

Vince, Natalya. "Saintly grandmothers: youth reception and reinterpretation of the national past in contemporary Algeria." The Journal of North African Studies 18, no.1 (2013), 32-50. Accessed July 11, 2014. Doi: 10.1080/13629387.2012.728049.

Weaver, Matthew. "Isis declares caliphate in Iraq and Syria." The Guardian. June 30, 2014. Accessed July $12,2014$. http://www.theguardian.com/world/middle-east-live/2014/jun/30/isis-declares-caliphate-in-iraq-and-syria-live-updates.

Wieland, Carsten. Syria. A Decade of Lost Chance. Seattle: Cune Press, 2012.

Yacoub Oweis, Khaled. "Syrian Actress treads New Stage in Syrian Protests." Reuters. January 5, 2013. Accessed July 10, 2014. http://uk.reuters.com/article/2012/01/05/us-syria-actress-idUSTRE8040WQ20120105.

Yazbek, Samar. A woman in the Crossfire. Translated by Max Weiss. London: Haus Publishing, 2012.

York, Jillian C. "Why Syria's arrested blogger, Razan Ghazzawi, is one of my heroes." The Guardian. December 5, 2011. Accessed July 11, 2014. http://www.theguardian.com/commentisfree/2011/dec/05/syria-arrested-blogger-razanghazzawi. 